\title{
NAOS OF THE KING DARA I No.(200) At Mallawy MuSeum
}

\author{
By \\ Dr. Marwa Mahmoud Mohammed \\ Lecturer of Ancient Egyptian Archaeology and the Near East \\ Faculty of Arts - Minya University
}

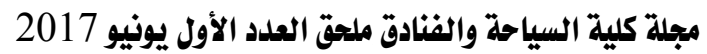

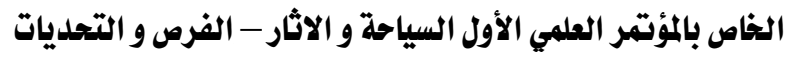




\section{NAOS OF THE KING DARA I No.(200) at Mallawy MuSEum \\ Dr. Marwa Mahmoud Mohammed ${ }^{1}$}

\section{Introduction:}

Naos $2 @$ is a box of stone or wood, surrounds the statue of a god to save and protect it, which is a wall that becomes difficult to penetrate. It has a door closed and sealed by the king who impersonates the role of the high priest. Hence, it is clear that kings and not the senior staff sealed most of the private sarcophagi. Specifically the kings between the Twenty Seventh and Thirtieth dynasties; during which the sarcophagi making became important and were placed in temples(fig.1).

\subsection{Object of study:}

A small wooden Naos in box, dating back to the Twenty Seventh dynasty, and later re-used by the Greco - Roman times at Tuna- El Gabal. The interior consisted of a baboon wrapped in linen wrappings. The baboon was the sacred animal symbolizing god Thoth, god of history and writing.

\subsection{The aim of the study:}

The research aims to study and classify the Naos by using equivalent researches, and deciphering the existing remaining texts. Furthermore, a general comment on the motifs and colours of the Naos, as well as, deities and their positions decorating the sides of the Naos. Throughout the study, it was concluded the influence of the effect of the Egyptian artistic features over the Persians during their stay in Egypt. The Naos has been redocumented at the museum ${ }^{3}$ to date back to the Twenty Seventh dynasty.

\section{Descriptive and analytical study ${ }^{4}$.}

\section{Lengths and sizes(fig.2): 2.1}

Front width: $28 \mathrm{~cm}$.

Side width: $34.5 \mathrm{~cm}$.

Height with the base: $42 \mathrm{~cm}$.

Cornice: $47 \mathrm{~cm}$.

Roof size: $30 \times 27 \mathrm{~cm}$.

Cornice size: $3 \times 27 \mathrm{~cm}$.

Size doorstep: $27 \times 3 \mathrm{~cm}$. 


\subsection{The frontal side:}

Naos has a high base covered with a layer of plaster, with colorful inscriptions decorating all sides. The upper part is surmounted by an Egyptian_cornice, The venter has a winged sun $\operatorname{disk}^{5}$, followed by a ledge (fig.3) with hieroglyphic inscriptions written in two opposite directions starting enh sign $f$

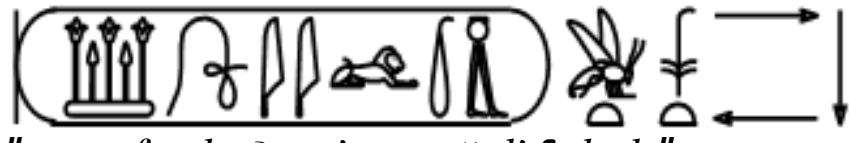

" ntr nfr nb t3wy intrywš di ' $n h \underline{d} \underline{d} t$ "

The good god, Lord of the two lands earths Antrocha ${ }^{6}$ eternal life

The cavetto cornice is an important architectural element, which was used to decorate upper parts sarcophagi. Some scholars believe that the cornice is possibly symbolizing the tradition of a palm sky of palm fronds from which the sun god descends and rises from. The latter architecture was a major purpose at the front of $\mathrm{Naos}^{7}$.

The Naos has a lid that opens up, similar to a door and bolt; it is used to close the door after the end of the burial rituals done on the god's statue $^{8}$. The Naos' door has the form of a horizon, hoping the god crossed with the sky goddess into the netherworld(fig.4).

The decorations represent a winged scarab above the winged sun disk. On both sides of the lid, the king wears the double crown atanding with his left

leg forward offering Alujat, which is placed as the sign " $n b^{\prime} \longrightarrow$, opposite him. The king's name was written in two cartouches flanking the door.

This was followed by a vertical writing of a rectangle reading the following text:

"nsw bity intrywš"

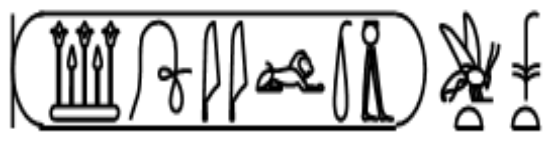

King of the Upper and Lower Antrocha.

In comparison to the amulet in the Louvre Museum at Paris(fig.5); it clearly noticeable that the lovely amulet to the left, which contains the name of the Achaemenid king Darius the Great was placed in a cartouche. It is not an ordinary amulet but the counterpoise is similar to the menat collar, which is a ritual necklace associated with goddess Hathor, goddess of love, joy, music and maternity. A common necklace, often worn by women ${ }^{9}$. 
"The good god, lord of the two lands, king of Upper and Lower Egypt, Darius; life forever"

Moreover, in comparison with the cartouche of Darius I, found in Temple of Hibis (fig.6) which is located in the New Valley governorate, of the $6^{\text {th }}$ century BCE, the Persian era. The cartouche of Darius I of Persia, as Pharaoh of Egypt reads as follows:

Son of Re, Lord of Appearances, the Great, Darius, given life

The lower parts of this side has geometric motifs; both in longitudinal and transversal directions, representing a façade of a royal palace known as

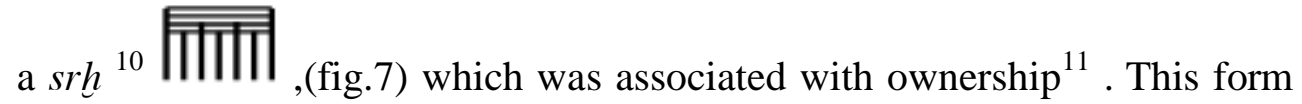
of decoration continued until the end of the Late Period, which was known by comparing the Naos of Darius I, which was found by Petri in Abosserpena in 1887 and now lies at the British Museum with the number $\boldsymbol{B} \boldsymbol{M}: 37496^{12}$.

As for goddess W3get, she appears wearing the white crown of the upper Egypt and other times wearing the lower red Egyptian crown (fig.8).

\subsection{The left side:}

On the left side King Dara kneels wearing a short pointed beard, and a blue crown surmounted by a cobra (fig.9). His eye was clearly drawn in a full frontal form and not the as commonly drawn sideways. The nose was done in square shape while the mouth has projecting lips. The artist wished to show part of the triangle patterned apron ${ }^{13}$.

Besides, the king sits above the façade of the palace, offering the

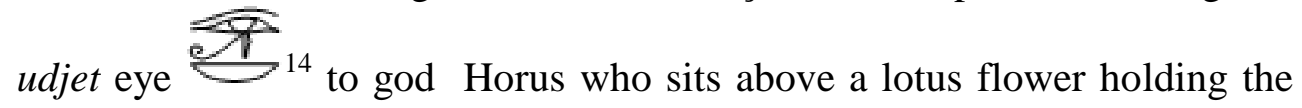
famous ' $n h$ sign of life in one of his hands. Horus protects the king along with the winged sky goddess $N w t$.

Below this scene, goddess Nehbet is also found winged with beautiful geometric motifs decorating the edges vertically and horizontally(fig.10).

\subsection{The back side:}

God hnum appears holding a w3s sign $\bigcap$, seated above an offering table surrounded by both the winged goddess W3get wearing an 3tf crown, and sitting on top of the $n b$ sign and a papyrus plant. Each deity has the

0

15 sign and a cartouche of King Dara(fig. 11). 
مجلة كلية السياحة والفنادق - ملحق العدد الأول يونيو 2017 الخاص بالمؤتمر العلمي الأول

A winged scarab holding solar disk above its head and the $\check{s} n$ sign of eternity. The text above the winged scarab reads (fig.12):

" ntr nfr nb t3wy intrywš di enh $\underline{d} t$ "

The good god, Lord of the two lands Antrocha, Giving eternal life""

Other sacred symbols decorate the walls of the Naos in order to renew the living soul of the king and the god so as to be activated to function in the netherworld. ${ }^{16}$

Also, the lower parts of the frontal side has geometric motifs longitudinal and transversal directions (fig.13).

\subsection{The right side:}

The right side is similar to the left side in all its details(fig.14).

\subsection{Upper surface (ceiling) of Naos :}

The ceiling of the Naos has the usual designs found in ancient Egyptian temples and tombs, where the lines cross, as well as, stars representing the sky, assuring the presence of Ra both by day from the east and by night from the west ${ }^{17}$ (fig.15) .

\section{Comparison:}

When comparing with the Naos of Darius I, which was found by F. Petrie in Abosserpena in 1887 and is now located at the British Museum (fig.16) BM:37496

Type: wooden door for King Dara I.

Size: Height $28 \mathrm{~cm}$, width $23.5 \mathrm{~cm}$

The same details appear but with different gods and offerings. King Dara I wears the same costume.

It is a Naos made of wood inlaid with blue and red colored glass. ${ }^{18}$ The upper part of the door is decorated with stars of the sky. The sky has a group of five-pointed stars, and below it is a winged sun disk.

King Dara I wears a short pointed beard and a royal 3tf crown while his name appears next to the crown as follows:

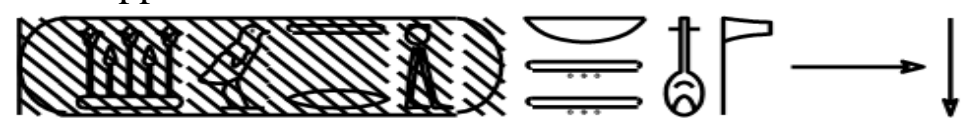

$n$ tr $n f r n b$ t3wy intrywš

The good god, Lord of the two lands Antrocha 
He raises both hands offering justice 迡 to god Anubis who stands before him. In his left hand he holds the $w 3 s$ sign , and a partial ${ }^{n} n h$ in his right hand while only remains of his name are left ${ }^{19}$ :

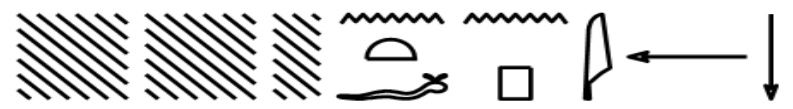

$\operatorname{Inp}(w)$

$n$

it. $(f) \ldots \ldots \ldots \ldots \ldots$

To his father Anubis

Behind King Dara I, goddess Isis holds in her left hand the

and in the other hand, the remaining vertical text above reads as follows $^{20}$ :

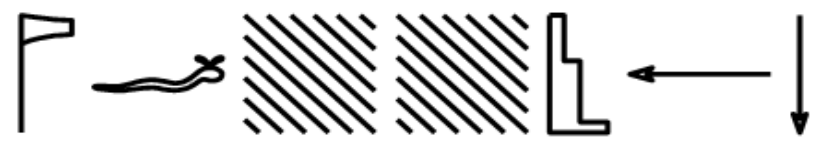

$3 s t \ldots \ldots \ldots . . . . f n t r$

Isis.............. the divine

The lower parts of this side also has geometric motifs in both longitudinal and transversal directions representing the royal palace façade known as srh.

Unfortunately, most of these sarcophagi have been abandoned, except for some of which were used during the Ptolemaic era ${ }^{21}$.

\section{Conclusion}

1- The artistic elements are Egyptian and have nothing to do with Greco-Roman art especially when compared with the Naos of Darius I (BM:37496) now in the British Museum

2- The cartouche of King Darius I has no other in comparison with the amulet in the Louvre Museum which contains the name of the Achaemenid, king Darius the Great in a cartouche.

3- Ancient Egyptians used many colors including red, green, yellow, black and blue.

4- The Naos type hnty- sh-ntr is associated with god Anubis, who supervises the process of embalming. This appeared since the time of the ancient state on the walls of tombs as part of the scenes transferring the 
مجلة كلية السياحة والفنادق - ملحق العلد الأول يونيو 2017 الخاص بالمؤتتر العلمي الأول

statue and even the pilgrimage. The repetitive use of the word sh-ntr since the Twenty Seventh dynasty as a nominative.

5- Ancient Egyptians were interested in the following technical elements:

The sky and the earth.-

Winged sun disk.-

Sacred symbols.-

The facade of the palace.-

The king appeared making offerings to the gods.-

6- From all the above, the date of the piece can be traced back to the Twenty Seventh Dynasty. Thus, the museum records need to be modified along with the museum's display cards.

\section{Pictures}

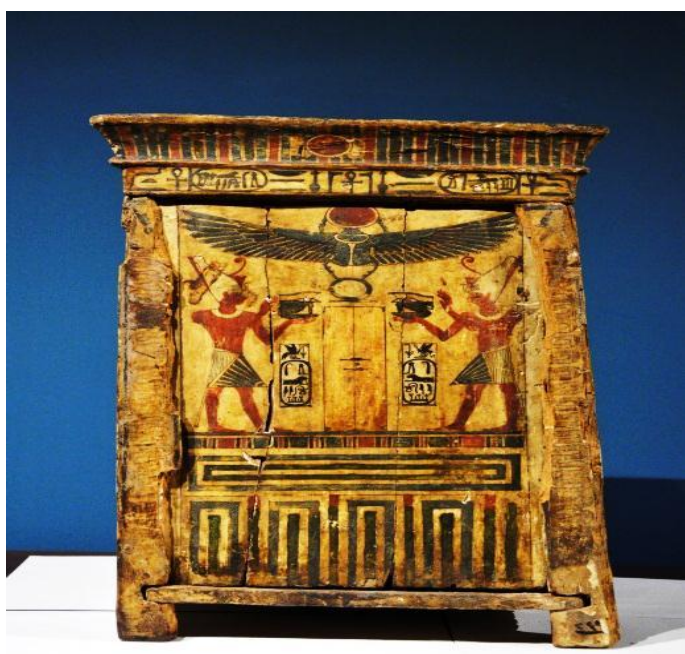

Fig.1 


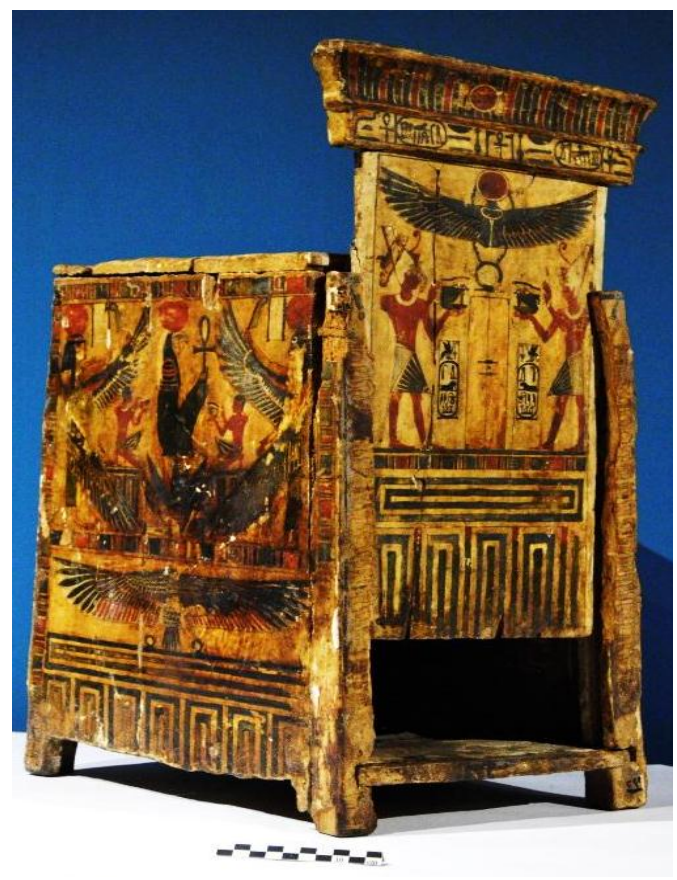

Fig.2.

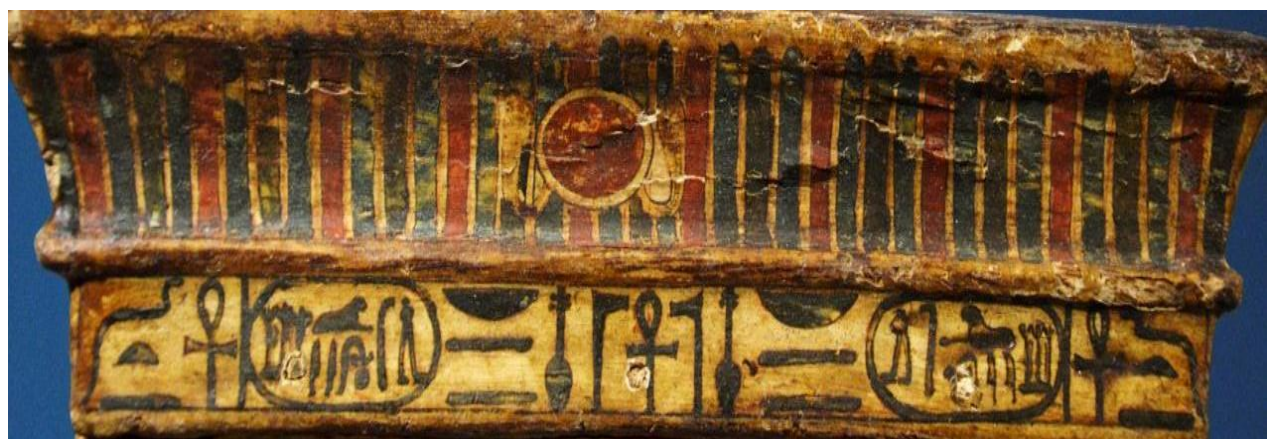

Fig.3. 


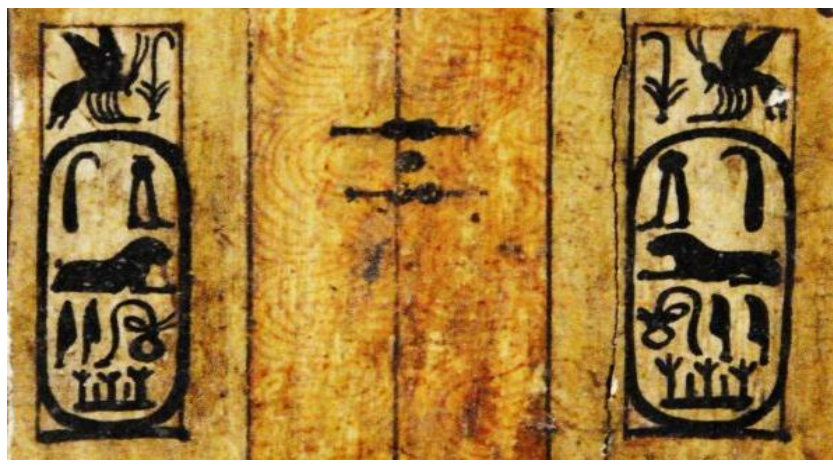

Fig.4.

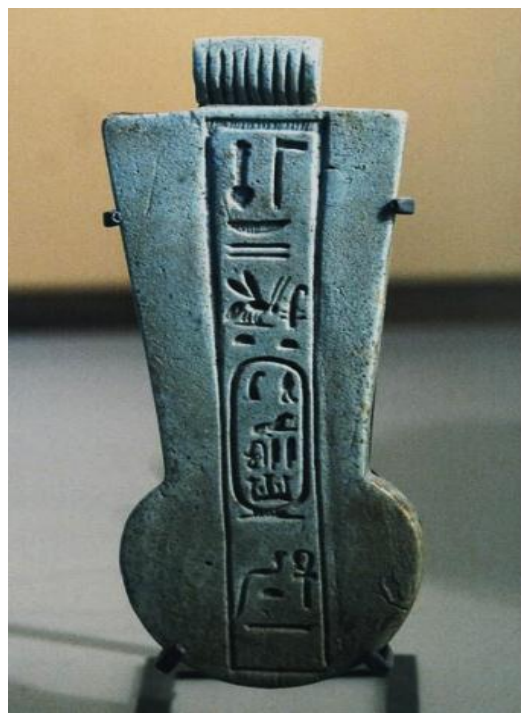

Fig.5 


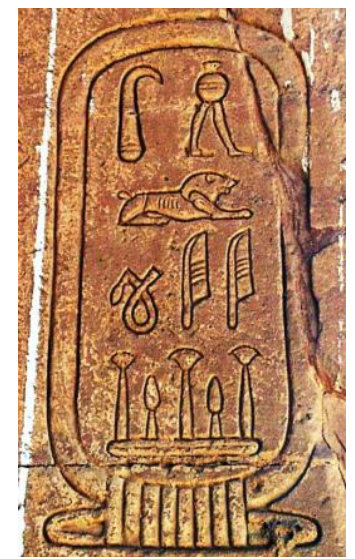

Fig.6

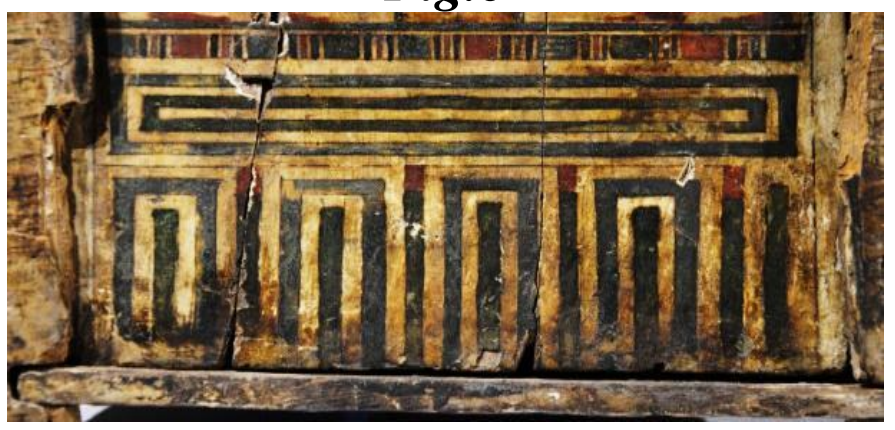

Fig.7.
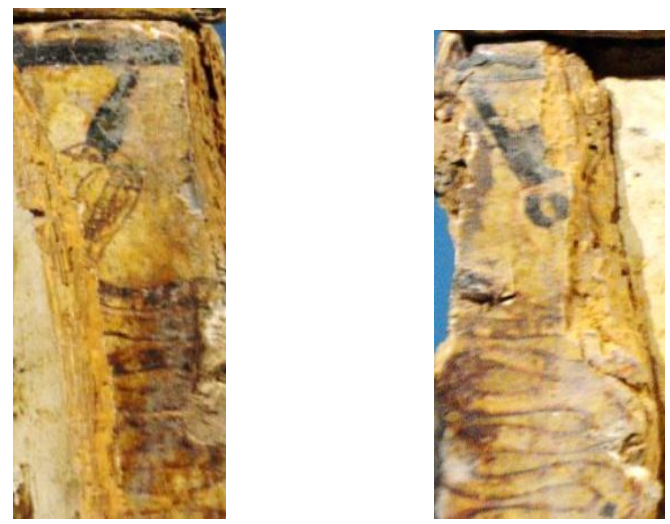

fig.8. 
مجلة كلية السياحة والفنادق - ملحق العلد الأول يونيو 2017 الخاص بالمؤتمر العلمي الأول ـــ

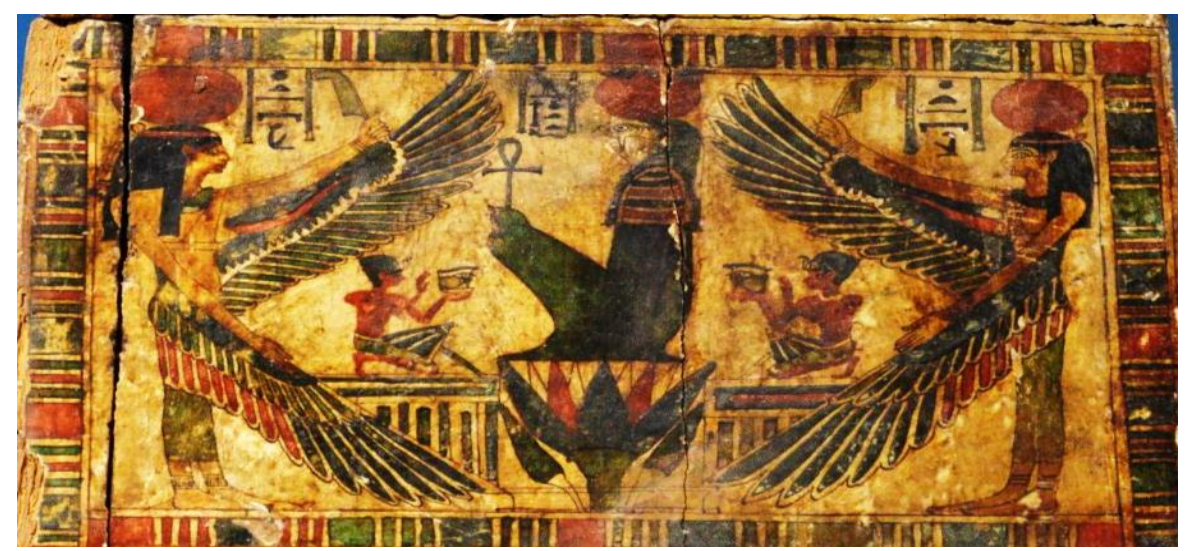

Fig.9.

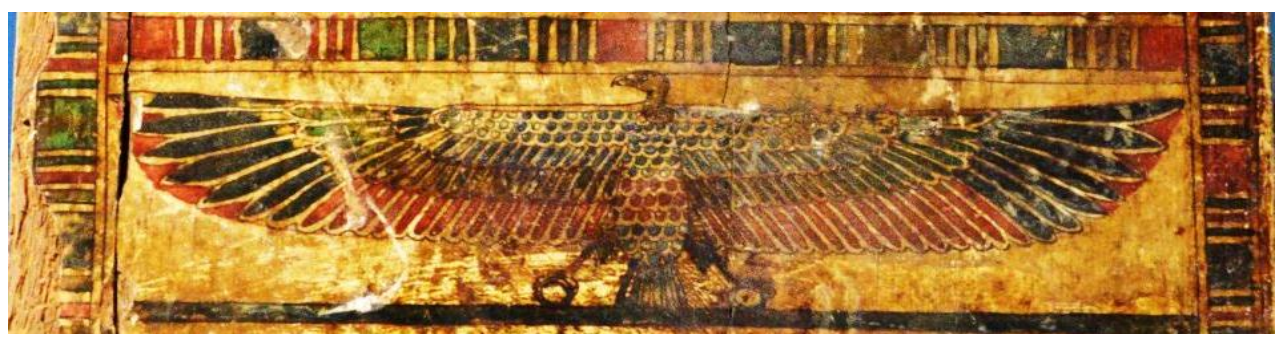

Fig.10

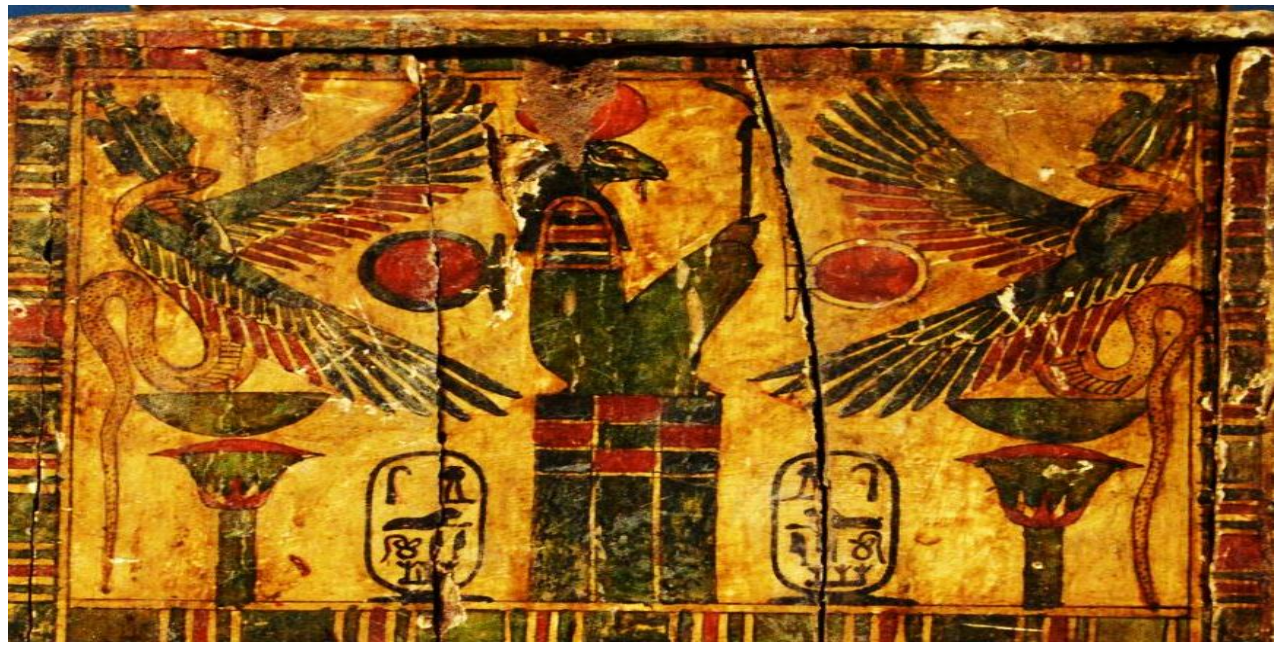

Fig.11 
Naos of the king Dara I No.(200) at Mallawy Museum

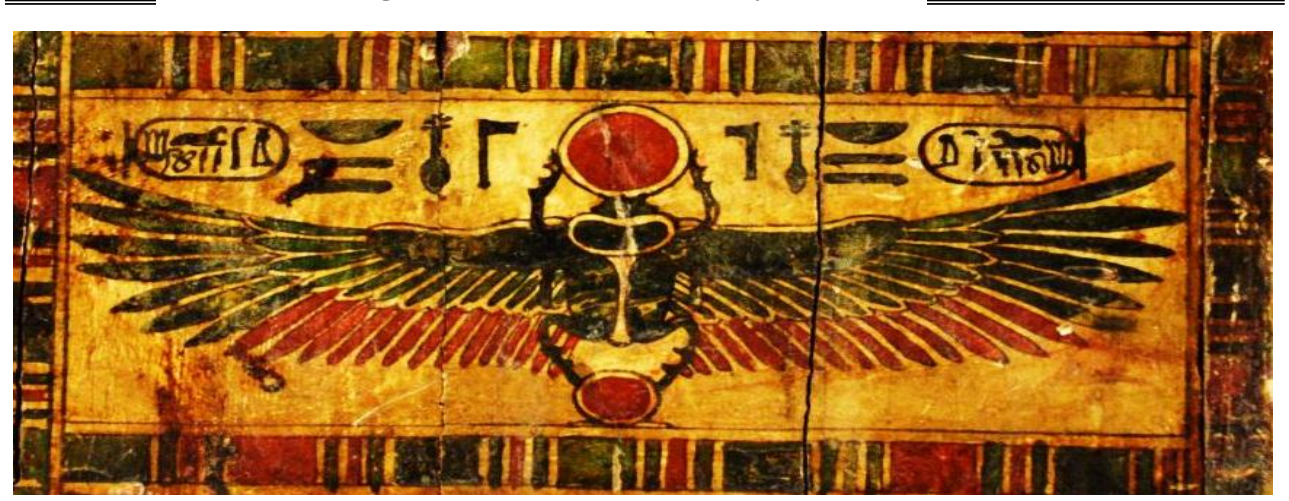

Fig.12.
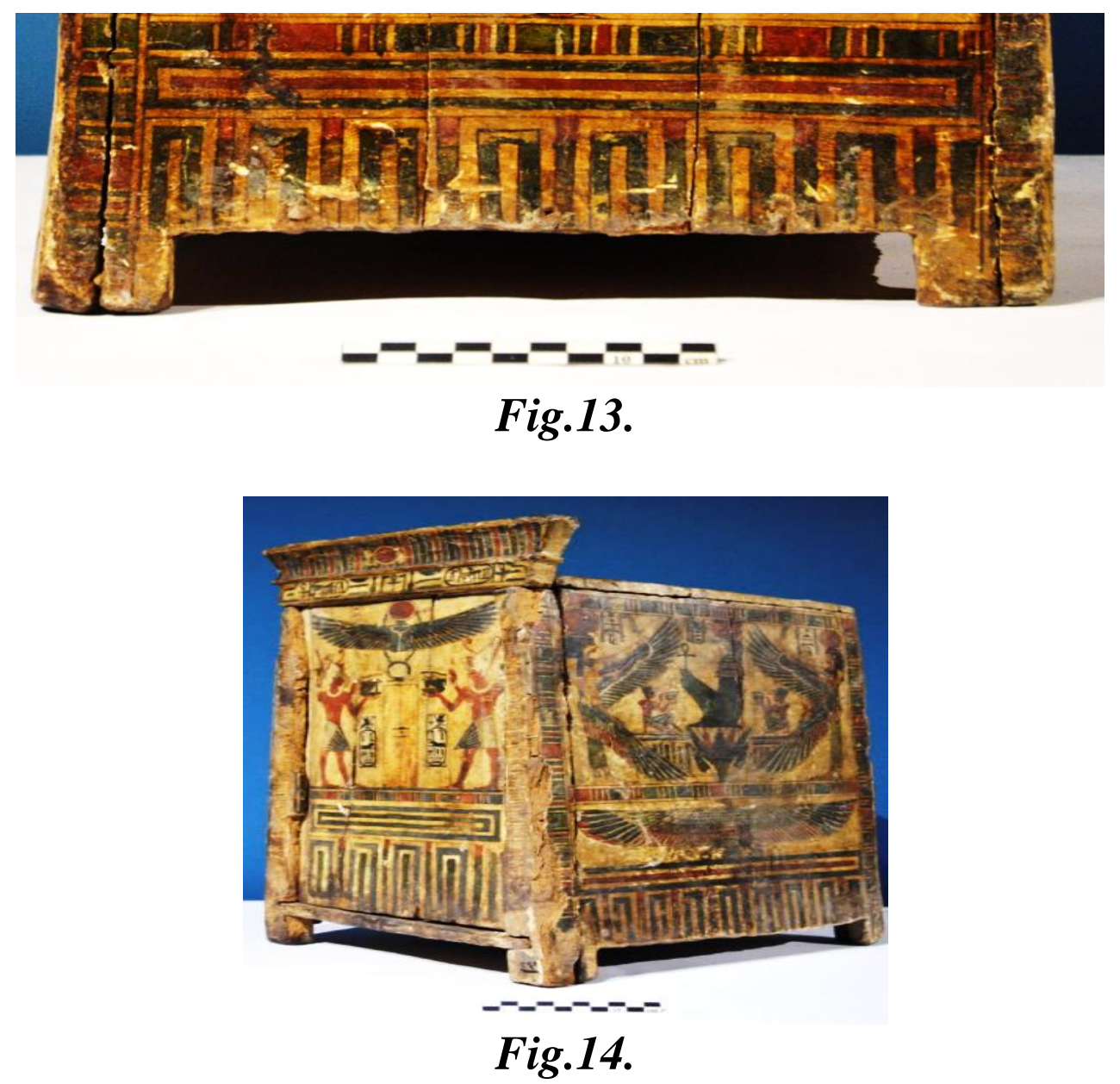
مجلة كلية السياحة والفنادق - ملحق العلد الأول يونيو 2017 الخاص بالمؤتمر العلبي الأول
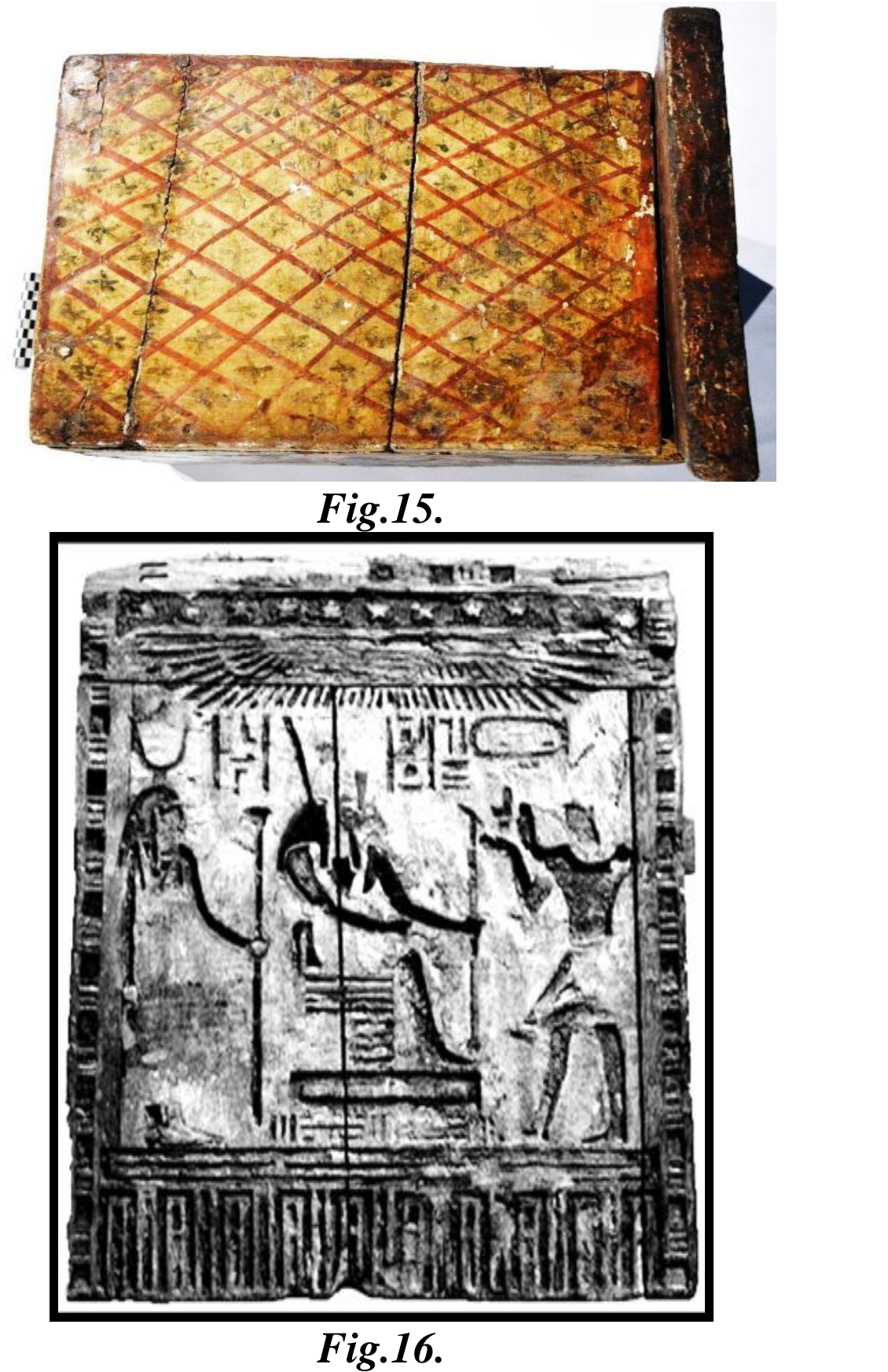
1 Lecturer of Ancient Egyptian Archaeology and the Near East Faculty of Arts - Minya University

${ }^{2}$ Naos: The word is a Greek word for cabin where there is a statue of the god inside the Holy of Holies/ sanctuary. It is of two types: fixed and movable.

- H. George., Greek-English Lexicon, Greek, 1943, p. 57

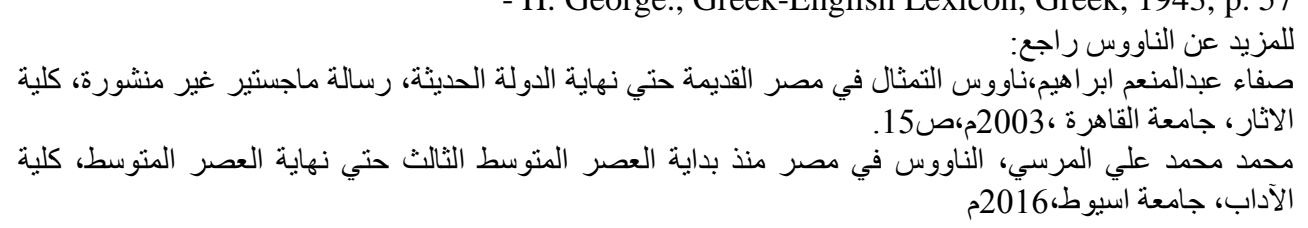

${ }^{3}$ H. Messiha \& M. A. Elhitta , Mallawi Antiquities Museum: A Brief Description, (Cairo, 1979), p. 15 (No ‘(200pl. XVI

Gabra, S., Lettres araméennes trouvées à Touna el Gebel Hermoupolis ouest, BIE 28, (1947), pp .162-161؛

$$
\begin{aligned}
& 4 \text { الوصف الكلي للناووس مجهود شخصي من الباحثة. } \\
& \text { تصوير الباحثة و المقاييس من رفع الباحثة. }
\end{aligned}
$$

5 winged sun disk: The winged sun is a symbol associated with divinity, royalty and power in the Ancient Near East Egypt, Mesopotamia, Anatolia, and Persia, the symbol is attested from the Old Kingdom (Sneferu, 26th century BC), often flanked on either side with a uraeus. In early Egyptian religion, the symbol Behedeti represented Horus of Edfu.

-H. Engelbach.,An Alleged Winged Sun Disk of the First Dynasty, ZÄS, Band 65,Leipzig,1930,pp115,116\&. A.H. Gardiner, Horus The Behdeti, JEA 30 (1944),p.49 -51.

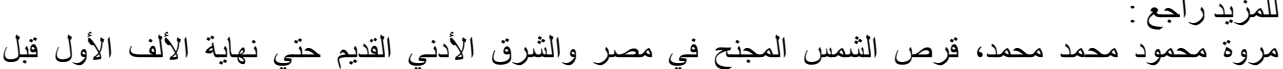

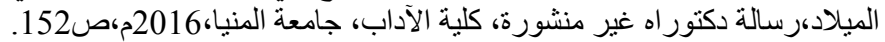

${ }^{6}$ Dara I: king of ancient Persia, whose reign lasted from 522 to 486 . He seized power after killing king Gaumâta, fought a civil war (described in the Behistun inscription), and was finally able to refound the Achaemenid empire, which had been very loosely organized until then. Darius fought several foreign wars, which brought him to India and Thrace. When he died, the Persian empire had reached its largest extent. He was succeeded by his son $\underline{\text { Xerxes }}$

- J.E. Curtis., \& N. Tallis., Forgotten Empire: The World of Ancient Paersia, London, 2005, Cat. 266.

7 , W.M.F. Petrie, Egyptian decorative Art, A course of lectures delivered at the Royal Institution, London: Methuen, 1895, pp. 89-99.

$$
\text { صفاء عبدالمنعم ابر اهيم، المرجع السابق،56 }
$$

8 H.G., Fischer., Egyptian Doors, Inside and Out, In Egyptian Studies III, New York, 1978, pp.91-92, 97-98.

${ }^{9}$ http://www.livius.org/pictures/a/egypt/amulet-of-darius.

10 A serekh: was an ornamental vignette combining a view of a palace facade and a plan (top view) of the royal courtyard. The word "serekh" derives from the Egyptian 
word for "facade". Different serekhs on different types of object display countless variations of the facade decor in its complexity and detail. It seems that no strict artistic rules for the design of the serekh itself existed, serekh was normally used as a royal crest, accentuating and honouring the name of the pharaoh. Its use can be dated back as early as the Gerzeh culture (ca. $3400 \mathrm{BC}$.). The hieroglyphs forming the king's name were placed inside a rectangular extension atop the serekh, which represented the royal courtyard. Additionally, the falcon of the god Horus, or in a few cases the Set animal, topped the serekh, showing the celestial patron of the named king.

-T. Wilkinson, Early Dynastic Egypt: Strategy, Society and Security. Rutledge, London, 1999,pp.201-202.

${ }^{11}$ D. Arnold., Temples of the last Pharaohs, Oxford University press, New York, 1999, p. 77 , fig. 37.

${ }^{12} \mathrm{http} / / / \mathrm{www}$.britishmuseum.org/research/search the collection_database/search_object. É. Naville., The mound of the Jew and the city of Onias: Belbeis, Samanood, Abusir, Tukh el Karmus.1887, EEF 7, London, 1890, p. 27, pl. VII. ،

13 Wadjet : The name Wadjet is derived from "wadj" meaning "green", hence "the green one", and was known to the Greeks and Romans as "uraeus" from the Egyptian "iaret" meaning "risen one" from the image of a cobra rising up in protection. Wadjet was one of the earliest of Egyptian deities who later became associated with other goddesses such as Bast, Sekhmet, Mut, and Hathor. She was the tutelary deity of Lower Egypt and the major Delta shrine the "per-nu" was under her protection. Hathor is also depicted with this eye In Egyptian myth the eye was not the passive organ of sight but more an agent of action, protection or wrath. Funerary amulets were often made in the shape of the Eye of Horus. The Wadjet or Eye of Horus is "the central element" of seven "gold, faience, carnelian and lapis lazuli" bracelets found on the mummy of Shoshenq II. ${ }^{[3]}$ The Wedjat "was intended to protect the pharaoh [here] in the afterlife"and to ward off evil. Ancient Egyptian and Middle-Eastern sailors would frequently paint the symbol on the bow of their vessel to ensure safe sea travel.

Wilkinson, R. H. The Complete Gods and Goddesses of Ancient Egypt. Thames \& Hudson,2003, p. 202.

Pinch, G , Egyptian Mythology: A Guide to the Gods, Goddesses, and Traditions of Ancient Egypt. Oxford University Press. 2004, pp. 131-132

James.A, Middle Egyptian: An Introduction to the Language and Culture of Hieroglyphs. Cambridge University Press. 2000, p. 426.

مفيدة حسن الوشاحي، الفنون في عصر الصحوة الأخيرة للحضارة المصرية القديمة، عصر الأسرات (27-30)، رسالة

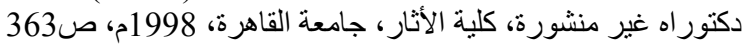

14 , W. Westendorf, “Altägyptische Darstellungen des Sonnenlaufes auf der Abschüssigen Himmelsbahn MÄS10 (1966), pp. 64 (52), 72 (60), pl. 71.

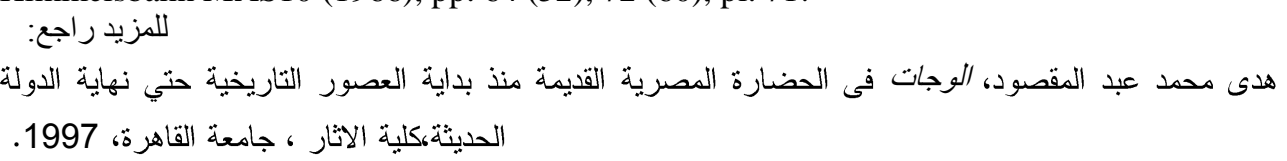


15 A shen ring: is a circle with a line at a tangent to it, which was represented in hieroglyphs as a stylised loop of a rope. The word shen itself means, in ancient Egyptian, encircle, while the shen ring represented eternal protection. In its elongated form the shen ring became the cartouche which enclosed and protected a royal name.

-B. Kemp.,. Ancient Egypt. Anatomy of a Civilisation. Routledge, Oxford,2007, p106.

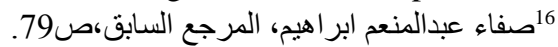

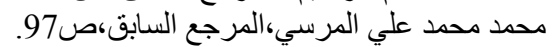

17 W. Westendorf, “Altägyptische Darstellungen des Sonnenlaufes auf der Abschüssigen Himmelsbahn, MÄS10 (1966), pp. 64 (52), 72 (60), pl. 71.

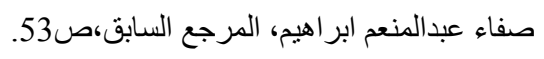

${ }^{18} \mathrm{http} / / /$ www.britishmuseum.org/research/search_the_collection_database/search_object.

19 J. Yoyotte., "Pétoubastis III", RdE 24 (1972), pp. 220-221, pl. 19.

P. Nicholson, \&L. Shaw., Ancient Egyptian Materials and Technology, Cambridge, 2000, p. 196.

H. Tait., Five Thousand years of Glass, London, 1991, pl. 62.

${ }^{20}$ L. Allen., The Persian Empire: A History, London, 2005, p. 110.

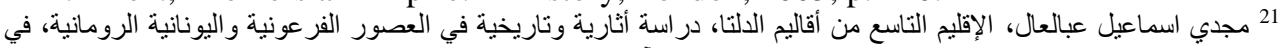

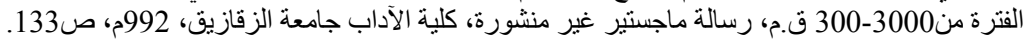

